\title{
Empirical Research on Board Structure and Corporate Performance Stability
}

\author{
Liu Fengwei ${ }^{1, a}$ \\ ${ }^{1}$ Shanghai City, Panlong road, 200, Shanghai National Accounting Institute, China \\ aliufengwei@snai.edu
}

\section{Keywords: Board Structure, Performance Stability, Decision Control}

\begin{abstract}
The board efficiency is an important topic in corporate governance. Previous studies focused on relationship between the board and company performance level, lack of in-depth analysis of the board and its influence on the major decision-making process and other forms of performance characteristics. This paper focuses on the relationship between corporate performance stability and structure of the board, which found board size and director source factors significantly affect the performance of the company. This paper proved that understanding the function of the board and the governance efficiency need more comprehensive perspective.
\end{abstract}

\section{Introduction}

Corporate board directors play a crucial role in modern corporate organizational structures. The quality of the board has become an important factor for the vast majority of investors to assess the company's quality after the Asian financial crisis. The existing researches payed more attention to the board of directors and corporate performance level to directly analyze the efficiency of the board governance, especially the relationship between the board structure and performance level (Yermack, 1996). Researches showed that the board scale, structure and corporate performance levels were significantly related, however, few scholars study board structure and corporate performance stability, ignoring the sustainability of enterprise quality and operating results. As for the modern corporation, keeping the lasting competitiveness is more important to efficiency of corporate governance.

The board usually decides the corporate decision production and formation. Board size and structure will significantly affect the corporate major decision-making process, time and the result, and brought profound impact on corporate performance. Financial performance reflect short-term operating results, verifying the economic consequences of corporate investment decision-making mechanism and process. The decision procession will not only affect the level of the future performance, but also impact the corporate performance persistence. So simple inspection of company performance and ignoring the variance of performance, cannot understand the economic consequences of the decision from a more comprehensive perspective, and cannot realize the operation of the board.

This paper takes Chinese listing company as research sample data from 2009 to 2013, to test the impact of the board size, characteristics on the stability of the performance of the company. The study found that board size has a significant negative correlation with performance standard deviation, such as return on total assets ratio, Tobin's Q, main business profit rate; the source of board directors more widely, the board size has more significant influence on the performance variance of the company.

\section{Literature review and research hypothesis}

\section{Literature review}

The conclusion is not consistent about the study on the relationship between the size of the board and corporate performance. With the expansion of the board, the coordination and communication between board members will become more difficult. For major decisions, if the communication is not smooth, which will not only reduce the work efficiency, but also cause personal problems or idea understanding deviation. Alexander (1993) pointed out that due to the larger board size, internal 
personnel constitute more complex, lack of cohesion, which are more likely to have different opinions. Yermack (1996) found that board size and corporate performance showed a significant negative correlation. But there are different research conclusions about the topic. Coles et.al (2006) showed that the board size had a positive impact on some companies, such as large Multi-National Corporation or large firms with diversification strategy. The management of these companies need more levels of knowledge and experience, so the large scale of board of directors can help them to acquire knowledge and avoid the risk, achieve the corporate strategic. Some scholars believe that, when the board size is in a certain range, which is the most favorable for companies. Hermalin and weisbach (2003) showed that the focus of research in the previous academic research, scholars have mainly concentrated in board size and structure on the performance level, almost few scholars concentrated on the board structure with the stability of the performance. Cheng (2007) found that the relationship between board size and firm performance stability showed a significant negative correlation. Adams (2005) study shows that the degree of centralization of power will directly affect the company's decision.

\section{Research hypothesis}

In summary, this paper studies the relationship between board characteristics and corporate performance stability. Because directors will affect the corporate decision making procession, different directors will have different opinions, the communication and coordination needed much time longer. The large board scale will ease the extreme degree of resolution of directors, because it needs more compromise and negotiation to reach consensus. Therefore, large-scale decisions of the directors will not be too extreme, neither the worst nor the best decision, the volatility of corporate performance will be more stable. This paper puts forward the following assumptions:

Hypothesis 1: when controlling other variables, the greater the size of the board, the higher stability of the corporate performance.

Due to complexity of decision formation, the board directors will affect the company's performance. The members of the board including inside and outside directors, chairman of the board serving as the general manager will affect the decisions of the board of directors. In addition, the sources of the board directors is negatively related to the performance of the company's stability. When a member of the board of directors appointed by the different shareholders nomination, the meeting of the board of directors decision will cause more representative of various views, so as to make the company more stable performance. To sum up, the paper puts forward the following assumptions:

Hypothesis 2: under the control of other variables, more board director sources, more independent directors, can improve performance stability; chairman board of directors and the general manager together can decrease the corporate performance stability.

\section{Sample source, model design and research results}

\section{Sample sources and model design}

This paper selects the samples for Chinese A stock market from 2009 to 2013 with all 5 years of financial data of the listing Corporation, excluding the missing data and financial companies, the remaining 702 Sample Firms. This paper uses data from the CSMAR database.

This paper selects Tobin Q, return on total assets, the main business income margin as alternative indicators of performance. Rate of return on total assets means the beginning of the book value divided by the end of the pre-tax profits of Listed Companies, Tobin's Q means the result of company value divided by the replacement value of assets; profit of main business income means the percentage of annual earnings divided by annual income.

The explanatory variables include two types, control variables and independent variables. Among them, the control variable is refers to the board of directors independence, financial leverage and influence, general manager influence, corporate growth, the rate of return on total assets one-year ago, the rate of return on total assets two-year ago, company ages and industry dummy variable. Independent variables included the board size, board director sources, independent directors and CEO power. Independent variables will be the size of the average value of the natural logarithm, 
shareholding ratio of more than $15 \%$ of the number of shareholders (often has the right to nominate directors, reflecting the directors' source diversity), the number of independent directors and general manager and chairman of the board of directors is a. To sum up, get the variables related to the empirical model. Table 1 is an empirical model to explain the variable.

Table 1 Variable definition

\begin{tabular}{|c|c|}
\hline Variables & Implications \\
\hline BS & Board size, the natural logarithm board members \\
\hline FH15 & Director source, numbers of ratio more than 15\% of shareholders \\
\hline IDN & Board independence, the number of independent directors \\
\hline CEO power & $\begin{array}{c}\text { Dummy variable, if the board chairman the same as the manager, } \\
\text { equal to 1, others 2 }\end{array}$ \\
\hline ID & Independent directors/board members \\
\hline DA & Leverage, debt divided by total asset \\
\hline ROA ( T-1 $)$ & Pre-tax profit $(\mathrm{t}-1) /$ total asset $(\mathrm{t}-2)$ \\
\hline ROA ( T-2 $)$ & Pre-tax profit $(\mathrm{t}-2) /$ total asset $(\mathrm{t}-3)$ \\
\hline FA & Company listing ages \\
\hline Industry & Industry dummy variable \\
\hline
\end{tabular}

This stability variables are explained by the YJWD, the standard deviation of performance. The explanatory variables are taken from the numerical average Sample Firms in sample period. According to Yermack (1996), Adams et al. (2005) and Cheng (2007), we construct model as follows:

$$
\mathrm{YJWD}=\alpha 0+\alpha 1 \mathrm{BS}+\alpha 2 \mathrm{FH} 15 * \mathrm{BS}+\alpha 3 \mathrm{IDN} * \mathrm{BS}+\alpha 4 \mathrm{CEOpower} * \mathrm{BS}+\alpha 5 \mathrm{ID}+\alpha 6 \mathrm{CEOpower}+\alpha 7 \mathrm{ROA}(
$$

$\mathrm{T}-1$ ) $+\alpha 8 \mathrm{ROA}(\mathrm{T}-2)+\alpha 9 \mathrm{CS}+\alpha 10 \mathrm{DA}+$ Industry $+\square \mathrm{i}$

We expect that the coefficient of BS, $\alpha 1$ is significantly negative, the coefficient of variable $\mathrm{FH} 15 * \mathrm{BS}$, $\alpha 2$ is significantly negative, the coefficient of variable IDN*BS, $\alpha 3$ is significantly negative, the coefficient of variable CEOpower*BS, $\alpha 4$ is significantly negative.

\section{Results}

The results of regression model shows that the board size variable BS is significantly negative correlated with ROA volatility, the $\mathrm{t}$ value is -2.51 ; FH15*BS is negatively correlated with ROA volatility, the significant level is 0.01 .The variable IDN*BS and CEOpower*BS have no significant correlation with the stability of the performance of ROA. The results are shown in table2. When we use other performance variable to calculate the standard deviation as the dependent variable,such as Tobin's Q and profit of main business income, we get the same results as the performance ROA. 
Table 2 Regression coefficients results

\begin{tabular}{|c|c|c|c|}
\hline & Std- ROA & Std- ROA & Std- ROA \\
\hline BS & $-0.02252^{* *}$ & $-0.43245^{* *}$ & -0.01457 \\
\hline FH15*BS & $-0.003953^{* * *}$ & & \\
\hline IDN*BS & & -0.00052 & \\
\hline CEOpower*BS & & & -0.01688 \\
\hline ID & -0.0366 & -0.63974 & -0.032 \\
\hline CEOpower & $-0.01581^{* * *}$ & -0.04822 & 0.020217 \\
\hline DA & $0.036253^{* * *}$ & 0.01133 & $0.036167^{* * *}$ \\
\hline ROA1 & $0.12432^{* *}$ & -0.49655 & $0.130512^{* *}$ \\
\hline ROA2 & $-0.17933^{* *}$ & 0.770368 & $-0.18216^{* * *}$ \\
\hline CS & $0.018819^{* * *}$ & $0.459436^{* * *}$ & $0.018147^{* * *}$ \\
\hline Industry & Control & Control & Control \\
\hline F value & 7.66 & 2.08 & 5.12 \\
\hline R-squared $(\%)$ & 19.88 & 6.3 & 14.22 \\
\hline Adj-Rsquared(\%) & 17.28 & 3.27 & 11.44 \\
\hline N & 702 & 702 & 702 \\
\hline
\end{tabular}

Noted : *,**, $* * *$ means $10 \%, 5 \%, 1 \%$ level significance.

Based on above results, we suggest the larger board size has a significant effect on stability of corporate performance. In addition, director background or sources are more widely, correlation of the board size and firm performance stability is stronger. These results testify the diversity of directors has an important influence on the stability of performance. Different source of directors will play an effective supervisory role on the decision procession and investment economic consequence.

\section{Conclusions}

The previous studies measure the efficiency of corporate governance on the performance of the company level, this paper pay more attention to the correlation between the board characters and the performance stability. After controlling the other variables affecting the performance of the company, the conclusions show that the larger board size, the stability of the corporate is higher. In addition, the background and diversity source of directors can increase this relationship. This shows that the members of the board of directors from different sources are significantly important to corporate governance efficiency. This paper proved that we should study the board, the one of the most important corporate governance mechanism, from a broader perspective, so as to provide important reference and enlightenment of improving the existing corporate governance theory and practice.

\section{Acknowledgements}

This work was financially supported by the youth project of National Natural Science Fund (71202045).

\section{References}

[1]Yermack, D.: Higher Market Valuation of Companies with a Small Board of Directors [J]. Journal of Financial Economies, 1996, Vol. 40:185-211. 
[2] Jeffrey A. Alexander, Mary L. Fennell, Michael T. Halpern.: Leadership Instability in Hospitals: The Influence of Board-CEO Relations and Organizational Growth and Decline [J]. Administrative Science Quarterly, 1993, Vol.38:74-99.

[3] Jeffrey L. Coles, Naveen D. Daniel, Lalitha Naveen. Boards: Does One Size Fit All? [J].Journal of Financial Economics, 2006.

[4] Hermalin BE, Weisbach MS.: Boards of directors as an endogenously determined institution: A survey of the economic literature [J]. Economic Policy Review, 2003:7-26.

[5] Cheng S. Board size and the variability of corporate performance[J]. Journal of Financial Economics, 2008, 87 (1): 157-176.

[6] Adams, R., Almeida. H., Ferreira, D.. Powerful CEOs and Their Impact on Corporate Performance[J]. Review of Financial Studies, 2005, Vol. 18:1403-1432. 